\title{
Independent of $5-\mathrm{HT}_{\mathrm{A}}$ receptors, neurons in the paraventricular hypothalamus mediate ACTH responses from MDMA
}

\author{
Dmitry V. Zaretsky ${ }^{\mathrm{a}}$, Maria V. Zaretskaia ${ }^{\mathrm{a}}$, Joseph A. DiMicco ${ }^{\mathrm{b}}$, Pamela J. Durant ${ }^{\mathrm{a}}$, Christian \\ T. Ross ${ }^{a}$, and Daniel E. Rusyniak ${ }^{a, b}$ \\ ${ }^{a}$ Department of Emergency Medicine, Indiana University School of Medicine, Indianapolis, IN, \\ 46202, United States \\ ${ }^{b}$ Department of Pharmacology and Toxicology, Indiana University School of Medicine, \\ Indianapolis, IN, 46202, United States
}

\section{Abstract}

Acute and chronic complications from the substituted amphetamine 3,4methylenedioxymethamphetamine (MDMA) are linked to activation of the hypothalamicpituitary-adrenal (HPA) axis. How MDMA activates the HPA axis is not known. HPA responses to stress are known to be mediated through the paraventricular (PVH) hypothalamus and to involve serotonin-1a $\left(5-\mathrm{HT}_{\mathrm{A}}\right)$ receptors. We sought to determine if the $\mathrm{PVH}$ and $5-\mathrm{HT} 1_{\mathrm{A}}$ receptors were also involved in mediating HPA responses to MDMA. Rats were pretreated with either saline or a $5-\mathrm{HT}_{\mathrm{A}}$ antagonist, WAY-100635 (WAY), followed by a systemic dose of MDMA (7.5 mg/kg i.v.). Animals pretreated with WAY had significantly lower plasma ACTH concentrations after MDMA. To determine if neurons in the PVH were involved, and if their involvement was mediated by $5-\mathrm{HT} 1_{\mathrm{A}}$ receptors, rats implanted with guide cannulas targeting the $\mathrm{PVH}$ were microinjected with the $\mathrm{GABA}_{\mathrm{A}}$ receptor agonist muscimol, aCSF, or WAY followed by MDMA. Compared to aCSF microinjections of muscimol significantly attenuated the MDMAinduced rise in plasma ACTH (126 vs. $588 \mathrm{pg} / \mathrm{ml}, P=<0.01)$. WAY had no effect. Our data demonstrates that neurons in the $\mathrm{PVH}$, independent of $5-\mathrm{HT} 1_{\mathrm{A}}$ receptors, mediate $\mathrm{ACTH}$ responses to MDMA.

\section{Introduction}

In humans and laboratory animals, MDMA activates the hypothalamic-pituitary-adrenal (HPA) axis thus increasing circulating concentrations of adrenocorticotropic hormone $(\mathrm{ACTH})$ and corticosteroids $[11,29]$. This activation has been linked to both acute and chronic complications. Acutely, corticosteroids facilitate the development of hyperthermia from MDMA. Rats which have had their adrenal or pituitary removed fail to develop, or have attenuated, hyperthermia [7, 38]. Alterations in the function of the HPA axis are also associated with chronic complications from MDMA. Compared to drug-naive subjects, habitual MDMA users have higher basal plasma ACTH concentrations and blunted stress responses [8]. Similar effects have been reported in persons with clinical depression and anxiety [19] linking the HPA axis to psychiatric problems in heavy MDMA users [26].

\section{(C) 2013 Elsevier Ireland Ltd. All rights reserved.}

Corresponding Author: Daniel E. Rusyniak, MD, Indiana University School of Medicine, Department of Emergency Medicine, 1050 Wishard Blvd, Rm 2200, Indianapolis, IN, USA 46202, Business: 317-630-7276, drusynia@iupui.edu.

Publisher's Disclaimer: This is a PDF file of an unedited manuscript that has been accepted for publication. As a service to our customers we are providing this early version of the manuscript. The manuscript will undergo copyediting, typesetting, and review of the resulting proof before it is published in its final citable form. Please note that during the production process errors may be discovered which could affect the content, and all legal disclaimers that apply to the journal pertain. 
Despite a connection between the HPA axis and its complications, how MDMA activates the HPA axis is not known. Experimental stress activates the HPA axis similar to that seen with MDMA [5]. These responses are suppressed, or prevented, by inhibiting neurons in the region the paraventricular hypothalamus $(\mathrm{PVH})[5] .5-\mathrm{HT} 1_{\mathrm{A}}$ receptors are also linked to stress responses: blocking $5-\mathrm{HT} 1_{\mathrm{A}}$ receptors, through systemic or intracerebral administration of $5-\mathrm{HT} 1_{\mathrm{A}}$ antagonists, reduces increase in ACTH from restraint stress [21, 22].

The $\mathrm{PVH}$ and $5-\mathrm{HT}_{\mathrm{A}}$ receptors may also play a role in MDMA's ACTH responses. MDMA is a potent serotonin releaser and activates neurons in the PVH [12, 14]. Furthermore, microinjecting, or perfusing, 5- $\mathrm{HT} 1_{\mathrm{A}}$ agonists into the $\mathrm{PVH}$ increases plasma ACTH concentrations $[2,31,32]$ and conversely, microinjections of the $5-\mathrm{HT} 1_{\mathrm{A}}$ antagonist WAY-100635 (WAY) into the PVH inhibit plasma ACTH increases evoked by the systemic administration of 8-OH-DPAT [31]. Based on this, we hypothesized that $5-\mathrm{HT}_{\mathrm{A}}$ receptors in the PVH were involved in ACTH responses to MDMA.

\section{Materials and Methods}

\section{Animals}

Male Sprague-Dawley rats (weight $300 \pm 20 \mathrm{~g}$; Harlan, Indianapolis, IN) were singly housed, maintained in a $12 \mathrm{~h} \mathrm{light/dark} \mathrm{cycle} \mathrm{beginning} \mathrm{at} 7 \mathrm{a} . \mathrm{m}$, and fed ad libitum. Experiments were conducted in isolated rooms between 10:00 a.m. and 2:00 p.m. Animals were acclimated to the experimental rooms for a minimum of $2 \mathrm{~h}$ before experiments. Care and use of rats was approved by the Indiana University Animal Care and Use Committee.

\section{Chemicals}

MDMA, generously provided by the NIH, was dissolved the day of the experiment in normal saline; injection volumes were $1 \mathrm{ml} / \mathrm{kg}$ body weight. Muscimol (Sigma-Aldrich, St. Louis, MO) was dissolved in artificial CSF (aCSF) and stored at $-20^{\circ} \mathrm{C}$ until the time of the experiment. WAY (Sigma-Aldrich) was dissolved in sterile saline and used fresh or stored until use at $-20^{\circ} \mathrm{C}$.

\section{Surgical preparation}

Animals were anaesthetized with a ketamine/xylazine cocktail $(80 \mathrm{mg} / \mathrm{kg}$ ketamine; 11.5 $\mathrm{mg} / \mathrm{kg}$ xylazine, i.p.), with supplemental doses provided as needed, femoral artery (for blood withdrawal) and venous (for drug administration) catheters were inserted as previously described $[1,36]$. For experiments involving microinjections, animals were placed in a stereotaxic apparatus and bilateral microinjection guide cannulas (26 gauge, Plastics One, Roanoke, VA) were positioned into the region of the PVH using the following coordinates: incisor bar $5 \mathrm{~mm}$ above the interaural line, 10 degree angle from the sagittal plane, AP 0.0 $\mathrm{mm}$; LR $\pm 2.1 \mathrm{~mm}$; HD $-7.3 \mathrm{~mm}$. Once inserted, cannulas were secured with stainless steel screws, Vetbond glue (3M, St. Paul, MN) and cranioplastic cement. Dummy-wire cannulas were inserted in the guides, and the rats returned to their home cages for a minimum of seven days.

\section{ACTH Measurement}

Blood $(0.35 \mathrm{ml})$ was withdrawn from arterial catheters and replaced with an equal volume of sterile saline. The syringes used for blood draws contained $60 \mu \mathrm{l}$ of a solution containing 10 $\mathrm{mg} / \mathrm{ml}$ EDTA and 50\% aprotinin. Samples were immediately transferred to $0.5 \mathrm{ml}$ Eppendorf tubes, and centrifuged at 12,100 $g$ for $26 \mathrm{sec}$ in a MiniSpin centrifuge (Eppendorf, Hamburg, Germany) to separate the plasma. Samples were stored at $-80^{\circ} \mathrm{C}$ until analyzed. 
Plasma ACTH concentrations were determined by RIA using a modification of a previously reported method [43]. This double antibody assay uses a rabbit antiserum (IgG Corp, Nashville, $\mathrm{TN}$ ) recognizing the $\mathrm{ACTH}_{5-18}$, and goat anti-rabbit globulin (EMD Millipore, Billerica, MA) to precipitate the antigen antibody complex. ACTH for RIA standards was from Bachem (Torrance, CA), and ${ }^{125}$ I-ACTH from Diasorin Inc (Stillwater, MN). Counts were recorded on a gamma counter (Cobra II, Perkin Elmer, Watham, MA) and duplicate standard curves were used.

\section{Experimental Protocols}

\section{Time Course of ACTH after MDMA}

We determined peak plasma concentrations of ACTH by taking blood samples from rats $(\mathrm{n}=4) 5 \mathrm{~min}$ before and 15, 30, 60, 120, and $180 \mathrm{~min}$ after an i.v. dose of MDMA (7.5 mg/ $\mathrm{kg}$ ). This MDMA dose causes temperature and cardiovascular responses mimicking those seen in human intoxication, results in plasma concentrations similar to humans taking recreational doses [10], and, microinjections of muscimol into the region of the DMH (a brain region associated with sympathetic responses to MDMA) attenuated temperature, cardiovascular, and behavioral responses produced by this dose [36]. Since intraperitoneal injections cause stress responses-including increases in plasma ACTH concentrations [27] —drugs were injected intravenously.

\section{The effect of a systemic dose of WAY on MDMA-induced increases in plasma ACTH}

To determine WAYs effects on plasma ACTH after MDMA, rats $(n=4)$ were pretreated (i.v.) with equal volumes of vehicle $(0.9 \% \mathrm{NaCl})$ or WAY $(0.5 \mathrm{mg} / \mathrm{kg})$ followed 5 min later by MDMA $(7.5 \mathrm{mg} / \mathrm{kg})$. After a 2-day washout animals were crossed-over to receive the other pretreatment followed by MDMA; the order of administration was random. Blood was withdrawn 5 min before WAY or saline and 15 min after MDMA. The WAY dose was the same we previously showed decreases MDMA locomotion [35] and prevents increases in plasma ACTH produced by the $5-\mathrm{HT} 1_{\mathrm{A}}$ agonist 8-OH-DPAT [41]. Although 8-OH-DPAT is both a $5-\mathrm{HT} 1_{\mathrm{A}}$ and 5-HT7 agonist, only its $1 \mathrm{~A}$ effects are linked to ACTH secretion[6]. Like many drugs WAY is selective but not specific for certain receptors. At high doses WAY antagonizes dopamine-4 (D4) receptors [25], however the concentration we used how is below that shown to block D4 receptors in vivo [25]

\section{Effect of muscimol or WAY microinjections on increases in plasma ACTH produced by MDMA}

To investigate whether the $\mathrm{PVH}$, and more specifically $5-\mathrm{HT} 1_{\mathrm{A}}$ receptors in the $\mathrm{PVH}$, play a role in endocrine responses to MDMA, we conducted the following experiment. Rats were acclimated to their cage (Raturn ${ }^{\circledR}$, Basi, Layfayette IN) overnight. Then, microinjectors (33 gauge, Plastics One) were connected to a $10 \mu \mathrm{l}$ Hamilton syringe with Teflon tubing (ID $0.12 \mathrm{~mm}$; OD $0.65 \mathrm{~mm}$; BASi). The syringe was mounted on an infusion pump (Model 200, KD Scientific, Holliston, MA) to microinject either $100 \mathrm{~nL}$ of aCSF, muscimol (80 pmol), or WAY $(0.5 \mathrm{nmol})$. Muscimol, a $\mathrm{GABA}_{\mathrm{A}}$ agonist, was used to suppress neuronal activity in the PVH where it has been shown to hyperpolarize neurons [16]. The dose used has been shown to decrease ACTH concentrations caused by stress [40]. The dose of WAY was the same we have previously shown prevents hypothermia, when microinjected into the medullary raphe pallidus, from a systemic dose of 8-OH-DPAT [35]. Solutions contained $0.25 \%$ fluorescent microspheres $(0.04 \mu \mathrm{m}$ in diameter; Invitrogen, Carlsbad, CA) to mark the injection site. Since placing microinjectors evokes a mild stress response, animals were left undisturbed for at least $1 \mathrm{~h}$ after the injectors were placed [44]. Blood was withdrawn to obtain baseline ACTH concentrations, then 5 min later animals were microinjected, over 30 
seconds, with muscimol, WAY, or aCSF and five min later MDMA (7.5 mg i.v.) was injected.

\section{Verification of microinjections}

At the conclusion of each experiment rats were injected with pentobarbital $(100 \mathrm{mg} / \mathrm{kg}$, i.v. $)$ and transcardially perfused with $30 \mathrm{ml}$ of cold saline $\left(4^{\circ} \mathrm{C}\right)$ followed by $30 \mathrm{ml}$ of $4 \%$ paraformaldehyde. Brains were removed and placed overnight $\left(a^{\circ}{ }^{\circ} \mathrm{C}\right)$ in $4 \%$ solution of paraformaldehyde and afterwards stored in a $30 \%$ sucrose solution until processed.

Using a cryostat (Leica Microsystems, Buffalo Grove, IL) $40 \mu \mathrm{m}$ coronal brain sections were cut and microsphere location was determined using a fluorescent microscope according to the atlas of Paxinos and Watson (47) by an observer blinded to group allocation.

\section{Data Analysis and Statistical Procedures}

Statistics and graphs were generated using Prism (Graphpad Software, San Diego, CA) software. ACTH was reported as change from baseline. In the time course experiment we ran a repeat measures ANOVA test with a Dunnett's post-hoc test comparing each value to baseline. Experiments with systemic WAY were analyzed using a paired Student t-test and microinjection experiments analyzed by ANOVA with a Tukey's HSD post-hoc analysis. In all of these experiments significance was defined as a $P$-value $<0.05$.

\section{Results}

\section{ACTH Time course andthe effect of systemic WAY}

An i.v. dose of MDMA caused a rapid increase in plasma ACTH concentrations (Fig. 1A). Peak concentrations occurred at $15 \mathrm{~min}$ and were $>1000 \%$ above baseline. Mean baseline and peak ACTH concentrations $( \pm 1$ SEM) were $72( \pm 11)$ and $893( \pm 167) \mathrm{pg} / \mathrm{ml}$ respectively.

WAY $(0.5 \mathrm{mg} / \mathrm{kg}$, i.v.) significantly decreased plasma ACTH concentrations evoked by MDMA (Fig 1B). Mean increases in ACTH ( \pm 1 SEM) in the WAY and Saline groups were $198( \pm 52)$ and $642( \pm 66) \mathrm{pg} / \mathrm{ml}$ respectively. Mean baseline concentrations $( \pm 1 \mathrm{SEM})$ for the WAY and saline groups were $55( \pm 6)$ and $66( \pm 15) \mathrm{pg} / \mathrm{ml}$.

\section{Microinjection sites}

Microinjection sites were confirmed by fluorescent microspheres as demonstrated in the representative brain section (Fig. 2A). The approximate centers of each microinjection were elucidated from the corresponding H\&E stained section (Fig. 2B) and plotted on schematic coronal sections in which the PVH was demarcated using drawings adapted from the atlas of Paxinos and Watson [33]. The total area encompassing all the injections for the PVH is shown in gray (2C). Injection sites extended in this region so that correct locations were attributed to injections between -1.8 to $-2.12 \mathrm{~mm}$ (from bregma) in the region of $\mathrm{PVH}$.

\section{Effect of muscimol or WAY microinjections on increases in plasma ACTH produced by MDMA}

Compared to aCSF, microinjections of muscimol into the PVH, but not WAY, significantly reduced increases in plasma ACTH evoked by MDMA (Fig. 3). There were no differences in mean baseline concentrations between aCSF $(65 \pm 17 \mathrm{pg} / \mathrm{ml})$, muscimol $(57 \pm 17 \mathrm{pg} / \mathrm{ml})$, or WAY $(74 \pm 21 \mathrm{pg} / \mathrm{ml})$ respectively. We have previously shown that microinjections of muscimol or aCSF do not by themselves significantly increase ACTH [1]. It is not known however whether microinjections of WAY into the region of the PVH affect ACTH 
concentrations, therefore, we conducted an additional experiment microinjecting either aCSF or WAY into the PVH followed by a systemic dose of saline ( $\mathrm{n}=4$ /group). There were no differences in mean change in plasma ACTH $(48 \pm 8 \mathrm{pg} / \mathrm{ml} \mathrm{v} 43 \pm 8 \mathrm{pg} / \mathrm{ml}, \mathrm{p}=0.4)$ or in baseline ACTH concentrations $(50 \pm 7 \mathrm{pg} / \mathrm{ml}$ v $32 \pm 13 \mathrm{pg} / \mathrm{ml})$.

\section{Discussion}

Our results show that $5-\mathrm{HT} 1_{\mathrm{A}}$ receptors and neurons in the region of the $\mathrm{PVH}$ are involved in HPA activation produced by MDMA, but that the location of the involved $5-\mathrm{HT}_{\mathrm{A}}$ receptors is outside of the $\mathrm{PVH}$.

Serotonin receptors are known to regulate plasma ACTH concentrations [23], and drugs that activate either $5-\mathrm{HT} 1_{\mathrm{A}}[18,21,23]$ or $5-\mathrm{HT} 2_{\mathrm{A}}[18,34]$ receptors increase circulating concentrations of ACTH. A potent releaser of serotonin, MDMA has effects on body temperature that are thought to involve $5-\mathrm{HT} 1_{\mathrm{A}}$ and $5-\mathrm{HT} 2_{\mathrm{A}}$ receptors $[15,30]$. Both receptors could mediate the neuroendocrine effects of MDMA. 5-HT1 ${ }_{\mathrm{A}}$ agonists (i.e., 8-OHDPAT) cause increase in ACTH concentrations that closely parallel those seen with MDMA (Fig. 1A) [18]. While we confirmed a role for 5- $\mathrm{HT}_{\mathrm{A}}$ receptors in $\mathrm{ACTH}$ responses to MDMA, our findings do not eliminate the additional involvement of $5-\mathrm{HT} 2 \mathrm{~A}$ receptors. In support of this, systemic injections of WAY reduce but do not abolish MDMA-induced increases in plasma ACTH (Fig. 1B). Data from Nash et al. supports a role for 5-HT2 A receptors as they showed that ketanserin and mianserin, at relatively high doses, decreased corticosterone concentrations after MDMA [29]. While both drugs antagonize 5-HT2 A receptors they also antagonize other monoaminergic receptors including alpha-1 receptors, which are linked to hypothalamic control of ACTH secretion [20]. Nash's study also seems to conflict with our WAY experiments. They reported that pindolol, a 5-HT1 $1_{\mathrm{A}}$ antagonist, did not prevent MDMA-induced increases in corticosterone [29]. Pindolol, however, has been shown to be a mixed 5-HT1 ${ }_{\mathrm{A}}$ agonist-antagonist [17], exhibiting both agonist [4, 39] and antagonist $[13,42]$ properties depending on dose and local serotonin concentrations. Nash used a dose of pindolol $(0.3 \mathrm{mg} / \mathrm{kg})$ below that shown to have $5-\mathrm{HT} 1_{\mathrm{A}}$ antagonist properties [13, 42].

The finding that the PVH was involved in MDMA-mediated ACTH responses suggests that MDMA activates neurons in the PVH - the primary site of corticotropin-releasing hormone synthesis[24]. Previous work has shown that $5-\mathrm{HT}_{1}$ receptors in the $\mathrm{PVH}$ mediate ACTH responses to both systemically and centrally administered $5-\mathrm{HT} 1_{\mathrm{A}}$ agonists $[2,31,32]$. When viewed in this light, we were surprised to find that $5-\mathrm{HT} 1_{\mathrm{A}}$ receptors in the $\mathrm{PVH}$ did not mediate ACTH responses from MDMA. One possible explanation for this is that we microinjected insufficient concentration of WAY effectively block $5-\mathrm{HT} 1_{\mathrm{A}}$ receptors. This however is unlikely as the dose of WAY was the same as that which when microinjected into the medullary raphe pallidus prevents hypothermia induced by a systemic dose of 8OH-DPAT [35]. Rather, we suggest that the location(s) of $5-\mathrm{HT}_{\mathrm{A}}$ receptors involved in MDMA-mediated effects on plasma ACTH are upstream of the PVH. There are numerous potential sites that send efferents to the PVH and which contain, or are known to be influenced by $5-\mathrm{HT} 1_{\mathrm{A}}$ receptors: e.g., dorsal raphe nucleus, the bed nucleus of the stria terminalis, the preoptic area of the hypothalamus, and the amygdala [9, 22, 37]. Many of these sites are also known to send GABAergic projections to the PVH [28], such that through the release of 5-HT, MDMA could disinhibit CRH neurons in the PVH. Any of these, or numerous other, sites could be involved. Another possibility is that WAY acted on $5-\mathrm{HT} 1_{\mathrm{A}}$ receptors at the level of the pituitary [3]. Since our data showed nearly complete suppression (78\%) when the PVH was inhibited we think this possibility is unlikely. Further work is needed to determine the site and mechanism of WAY's action on increases in plasma ACTH seen after administration of MDMA. 
In conclusion, we have shown that neurons in the PVH are involved in to the activation of the HPA axis mediated by the substituted amphetamine MDMA. Furthermore we have shown that $5-\mathrm{HT} 1_{\mathrm{A}}$ receptors outside of the PVH are involved. Understanding how the HPA axis is activated by MDMA and other amphetamines may shed light on the mechanisms behind their acute and chronic complications.

\section{Acknowledgments}

Research reported in this publication was supported by the National Institute on Drug Abuse of the NIH under award number R01DA026867. Furthermore, this work was conducted in a facility constructed with support from the National Center for Research Resources, of the NIH under award number C06 RR015481-010. The content is solely the responsibility of the authors and does not necessarily represent the official views of the NIH.

\section{Abbreviations}

MDMA 3,4-methylenedioxymethamphetamine

HPA

ACTH adrenocorticotropin releasing hormone

5-HT1A serotonin-1a receptors, $\mathrm{PVH}$, paraventricular hypothalamus

PVH paraventricular hypothalamus

WAY WAY-100635

aCSF artificial cerebrospinal fluid

\section{References}

1. Bailey TW, DiMicco JA. Chemical stimulation of the dorsomedial hypothalamus elevates plasma ACTH in conscious rats. Am J Physiol Regul Integr Comp Physiol. 2001; 280:R8-15. [PubMed: 11124128]

2. Bluet Pajot MT, Mounier F, di Sciullo A, Schmidt B, Kordon C. Differential sites of action of 8OHDPAT, a 5HT1A agonist, on ACTH and PRL secretion in the rat. Neuroendocrinology. 1995; 61:159-166. [PubMed: 7753334]

3. Calogero AE, Bagdy G, Szemeredi K, Tartaglia ME, Gold PW, Chrousos GP. Mechanisms of serotonin receptor agonist-induced activation of the hypothalamic-pituitary-adrenal axis in the rat. Endocrinology. 1990; 126:1888-1894. [PubMed: 2156670]

4. Clifford EM, Gartside SE, Umbers V, Cowen PJ, Hajós M, Sharp T. Electrophysiological and neurochemical evidence that pindolol has agonist properties at the 5-HT1A autoreceptor in vivo. $\mathrm{Br}$ J Pharmacol. 1998; 124:206-212. [PubMed: 9630361]

5. DiMicco JA, Samuels BC, Zaretskaia MV, Zaretsky DV. The dorsomedial hypothalamus and the response to stress: part renaissance, part revolution. Pharmacol Biochem Behav. 2002; 71:469-480. [PubMed: 11830181]

6. Faure C, Mnie-Filali O, Scarna H, Debonnel G, Haddjeri N. Effects of the 5-HT7 receptor antagonist SB-269970 on rat hormonal and temperature responses to the 5-HT1A/7 receptor agonist 8-OH-DPAT. Neurosci Lett. 2006; 404:122-126. [PubMed: 16759802]

7. Fernandez F, Aguerre S, Mormède P, Chaouloff F. Influences of the corticotropic axis and sympathetic activity on neurochemical consequences of 3,4-methylenedioxymethamphetamine (MDMA) administration in Fischer 344 rats. European Journal of Neuroscience. 2002; 16:607-618. [PubMed: 12270036]

8. Gerra G, Bassignana S, Zaimovic A, Moi G, Bussandri M, Caccavari R, Brambilla F, Molina E. Hypothalamic-pituitary-adrenal axis responses to stress in subjects with 3,4-methylenedioxymethamphetamine ('ecstasy') use history: correlation with dopamine receptor sensitivity. Psychiatry Res. 2003; 120:115-124. [PubMed: 14527643] 
9. Gray TS, Carney ME, Magnuson DJ. Direct projections from the central amygdaloid nucleus to the hypothalamic paraventricular nucleus: possible role in stress-induced adrenocorticotropin release. Neuroendocrinology. 1989; 50:433-446. [PubMed: 2554178]

10. Green AR, Gabrielsson J, Marsden CA, Fone KC. MDMA: on the translation from rodent to human dosing. Psychopharmacology (Berl). 2009; 204:375-378. [PubMed: 19139850]

11. Grob CS, Poland RE, Chang L, Ernst T. Psychobiologic effects of 3,4methylenedioxymethamphetamine in humans: methodological considerations and preliminary observations. Behav Brain Res. 1996; 73:103-107. [PubMed: 8788485]

12. Gudelsky GA, Yamamoto BK. Actions of 3,4-methylenedioxymethamphetamine (MDMA) on cerebral dopamineric, serotonergic and cholinergic neurons. Pharmacol Biochem Behav. 2007; 90:198-207. [PubMed: 18035407]

13. Guilloux JP, David DJ, Guiard BP, Chenu F, Repérant C, Toth M, Bourin M, Gardier AM. Blockade of 5-HT1A receptors by (+/-)-pindolol potentiates cortical 5-HT outflow, but not antidepressant-like activity of paroxetine: microdialysis and behavioral approaches in 5-HT1A receptor knockout mice. Neuropsychopharmacology. 2006; 31:2162-2172. [PubMed: 16452992]

14. Hargreaves GA, Hunt GE, Cornish JL, McGregor IS. High ambient temperature increases 3,4methylenedioxymethamphetamine (MDMA, "ecstasy")-induced Fos expression in a regionspecific manner. Neuroscience. 2007; 145:764-774. [PubMed: 17289273]

15. Herin DV, Liu S, Ullrich T, Rice KC, Cunningham KA. Role of the serotonin 5-HT2A receptor in the hyperlocomotive and hyperthermic effects of (+)-3,4-methylenedioxymethamphetamine. Psychopharmacology (Berl). 2005; 178:505-513. [PubMed: 15765263]

16. Hewitt SA, Bains JS. Brain-derived neurotrophic factor silences GABA synapses onto hypothalamic neuroendocrine cells through a postsynaptic dynamin-mediated mechanism. J Neurophysiol. 2006; 95:2193-2198. [PubMed: 16407427]

17. Hjorth S, Carlsson A. Is pindolol a mixed agonist-antagonist at central serotonin (5-HT) receptors? Eur J Pharmacol. 1986; 129:131-138. [PubMed: 2429847]

18. Hofmann CE, Ellis L, Yu WK, Weinberg J. Hypothalamic-pituitary-adrenal responses to 5-HT1A and 5-HT2A/C agonists are differentially altered in female and male rats prenatally exposed to ethanol. Alcohol Clin Exp Res. 2007; 31:345-355. [PubMed: 17250628]

19. Holsboer F. Stress, hypercortisolism and corticosteroid receptors in depression: implicatons for therapy. J Affect Disord. 2001; 62:77-91. [PubMed: 11172875]

20. Itoi K, Suda T, Tozawa F, Dobashi I, Ohmori N, Sakai Y, Abe K, Demura H. Microinjection of norepinephrine into the paraventricular nucleus of the hypothalamus stimulates corticotropinreleasing factor gene expression in conscious rats. Endocrinology. 1994; 135:2177-2182. [PubMed: 7956940]

21. Jørgensen H, Kjaer A, Warberg J, Knigge U. Differential effect of serotonin 5-HT(1A) receptor antagonists on the secretion of corticotropin and prolactin. Neuroendocrinology. 2001; 73:322333. [PubMed: 11399905]

22. Jørgensen H, Knigge U, Kjaer A, Vadsholt T, Warberg J. Serotonergic involvement in stressinduced ACTH release. Brain Res. 1998; 811:10-20. [PubMed: 9804868]

23. Jørgensen HS. Studies on the neuroendocrine role of serotonin. Dan Med Bull. 2007; 54:266-288. [PubMed: 18208678]

24. Lennard DE, Eckert WA, Merchenthaler I. Corticotropin-releasing hormone neurons in the paraventricular nucleus project to the external zone of the median eminence: a study combining retrograde labeling with immunocytochemistry. J Neuroendocrinol. 1993; 5:175-181. [PubMed: 8485552]

25. Marona-Lewicka D, Nichols DE. Potential serotonin 5-HT(1A) and dopamine D(4) receptor modulation of the discriminative stimulus effects of amphetamine in rats. Behav Pharmacol. 2011; 22:508-515. [PubMed: 21814134]

26. Matthews AJ, Bruno R. An investigation of factors associated with depressive symptoms among a sample of regular ecstasy consumers. Neuropsychobiology. 2010; 61:215-222. [PubMed: 20389132]

27. Moldow RL, Fischman AJ. Cocaine induced secretion of ACTH, beta-endorphin, and corticosterone. Peptides. 1987; 8:819-822. [PubMed: 2829143] 
28. Myers B, Mark Dolgas C, Kasckow J, Cullinan WE, Herman JP. Central stress-integrative circuits: forebrain glutamatergic and GABAergic projections to the dorsomedial hypothalamus, medial preoptic area, and bed nucleus of the stria terminalis. Brain Struct Funct. 2013

29. Nash JF Jr, Meltzer HY, Gudelsky GA. Elevation of serum prolactin and corticosterone concentrations in the rat after the administration of 3,4-methylenedioxymethamphetamine. $\mathrm{J}$ Pharmacol Exp Ther. 1988; 245:873-879. [PubMed: 2898523]

30. Ootsuka Y, Nalivaiko E, Blessing WW. Spinal 5-HT2A receptors regulate cutaneous sympathetic vasomotor outflow in rabbits and rats; relevance for cutaneous vasoconstriction elicited by MDMA (3,4-methylenedioxymethamphetamine, "Ecstasy") and its reversal by clozapine. Brain Res. 2004; 1014:34-44. [PubMed: 15212989]

31. Osei-Owusu P, James A, Crane J, Scrogin KE. 5-Hydroxytryptamine 1A Receptors in the Paraventricular Nucleus of the Hypothalamus Mediate Oxytocin and Adrenocorticotropin Hormone Release and Some Behavioral Components of the Serotonin Syndrome. J Pharmacol Exp Ther. 2005; 313:1324-1330. [PubMed: 15743927]

32. Pan L, Gilbert F. Activation of 5-HT1A receptor subtype in the paraventricular nuclei of the hypothalamus induces CRH and ACTH release in the rat. Neuroendocrinology. 1992; 56:797-802. [PubMed: 1369587]

33. Paxinos, G.; Watson, C. The Rat Brain in Stereotaxic Coordinates. Academic Press; New York: 1998.

34. Rittenhouse PA, Bakkum EA, Levy AD, Li Q, Carnes M, van de Kar LD. Evidence that ACTH secretion is regulated by serotonin2A/2C (5-HT2A/2C) receptors. J Pharmacol Exp Ther. 1994; 271:1647-1655. [PubMed: 7996480]

35. Rusyniak DE, Zaretskaia MV, Zaretsky DV, DiMicco JA. 3,4- Methylenedioxymethamphetamineand 8-hydroxy-2-di-n-propylamino-tetralin-induced hypothermia: role and location of 5hydroxytryptamine 1A receptors. J Pharmacol Exp Ther. 2007; 323:477-487. [PubMed: 17702902]

36. Rusyniak DE, Zaretskaia MV, Zaretsky DV, DiMicco JA. Microinjection of muscimol into the dorsomedial hypothalamus suppresses MDMA-evoked sympathetic and behavioral responses. Brain Res. 2008; 1226:116-123. [PubMed: 18586013]

37. Sawchenko PE, Swanson LW. The organization of forebrain afferents to the paraventricular and supraoptic nuclei of the rat. J Comp Neurol. 1983; 218:121-144. [PubMed: 6886068]

38. Sprague JE, Banks ML, Cook VJ, Mills EM. Hypothalamic-pituitary-thyroid axis and sympathetic nervous system involvement in hyperthermia induced by 3,4-methylenedioxymethamphetamine (Ecstasy). J Pharmacol Exp Ther. 2003; 305:159-166. [PubMed: 12649364]

39. Sprouse J, Braselton J, Reynolds L. 5-HT(1A) agonist potential of pindolol: electrophysiologic studies in the dorsal raphe nucleus and hippocampus. Biol Psychiatry. 2000; 47:1050-1055. [PubMed: 10862804]

40. Stotz-Potter EH, Morin SM, DiMicco JA. Effect of microinjection of muscimol into the dorsomedial or paraventricular hypothalamic nucleus on air stress-induced neuroendocrine and cardiovascular changes in rats. Brain Res. 1996; 742:219-224. [PubMed: 9117398]

41. Vicentic A, Li Q, Battaglia G, Van de Kar LD. WAY-100635 inhibits 8-OH-DPAT-stimulated oxytocin, ACTH and corticosterone, but not prolactin secretion. Eur J Pharmacol. 1998; 346:261266. [PubMed: 9652368]

42. Wozniak KM, Aulakh CS, Hill JL, Murphy DL. The effect of 8-OH-DPAT on temperature in the rat and its modification by chronic antidepressant treatments. Pharmacol Biochem Behav. 1988; 30:451-456. [PubMed: 2971978]

43. Zaretskaia MV, Zaretsky DV, Shekhar A, DiMicco JA. Chemical stimulation of the dorsomedial hypothalamus evokes non-shivering thermogenesis in anesthetized rats. Brain Res. 2002; 928:113125. [PubMed: 11844478]

44. Zaretsky DV, Zaretskaia MV, Rusyniak DE, DiMicco JA. Stress-free microinjections in conscious rats. J Neurosci Methods. 2011; 199:199-207. [PubMed: 21600924] 


\section{Highlights}

- MDMA increases plasma ACTH levels

- Systemic WAY-100635 prevents these ACTH increases

- Inhibiting of neurons in the PVH also prevents these ACTH increases

- Microinjections of WAY-100635 into the PVH do not prevent ACTH increases

- Activation of HPA axis by MDMA separately involves 5-HT1a receptors and PVH neurons 

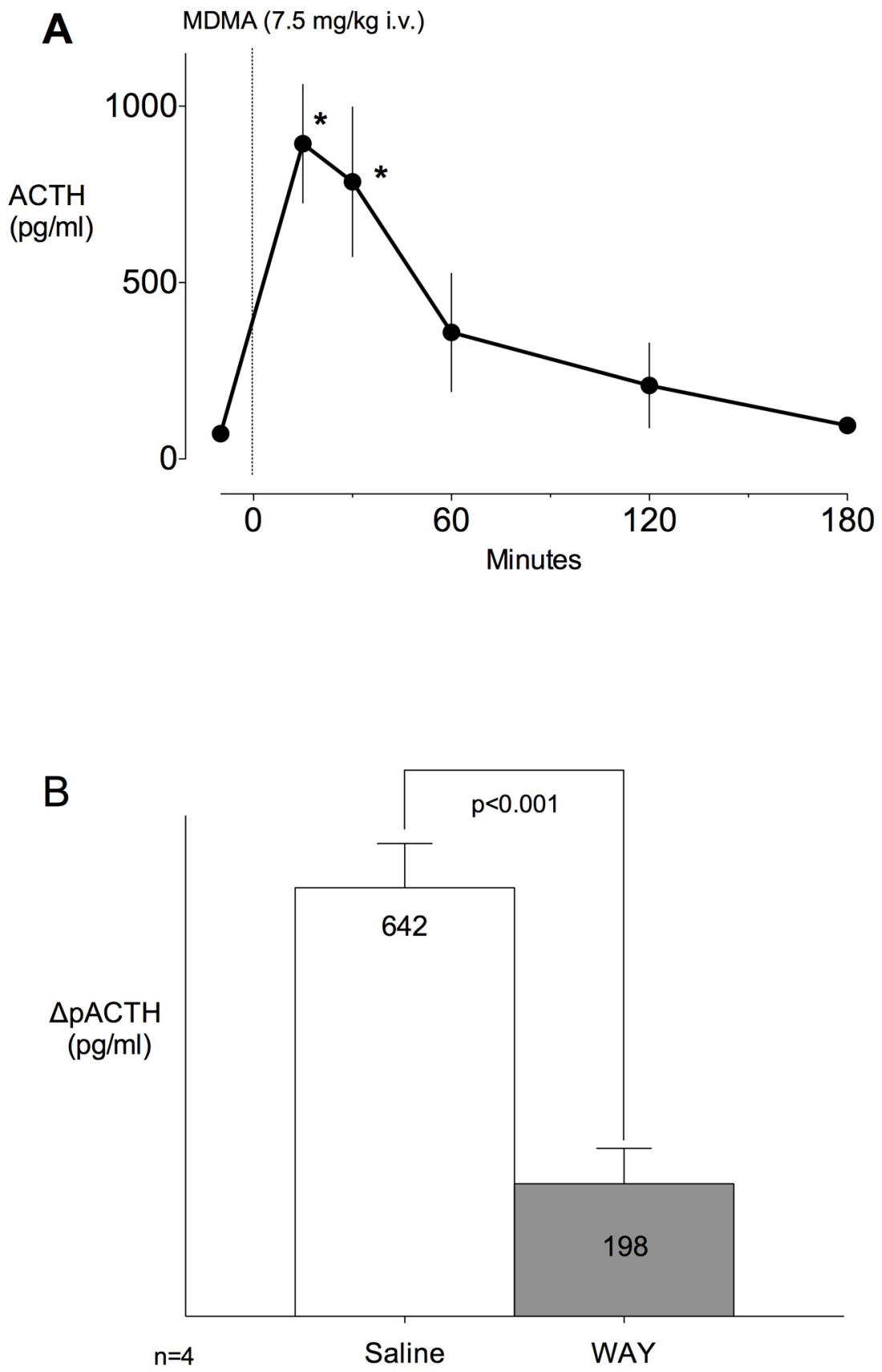

Fig 1.

Fig. 1A. Intravenous injection of MDMA causes a rapid and significant rise in ACTH. Circles represent mean ACTH concentrations and correspond to the time points when blood was withdrawn for measurement $(-10,15,30,60,120$, and $180 \mathrm{~min})$. Error bars represent 1 SEM. *Represent significant difference compared to baseline ACTH concentrations as determined by repeat measures ANOVA with a Dunnett's post hoc analysis. Fig. 1B. A systemic dose of WAY attenuates increases in ACTH produced by MDMA. Vertical rectangular bars, and their corresponding numbers, represent the mean change in plasma ACTH after a dose of MDMA $(7.5 \mathrm{mg} / \mathrm{kg})$ for animals previously injected with WAY $(0.5$ 
$\mathrm{mg} / \mathrm{kg}$, i.v.) or saline. Error bars represent $1 \mathrm{SEM}$. The $P$-value for comparison between the WAY and Saline groups is represented (paired t-test). 

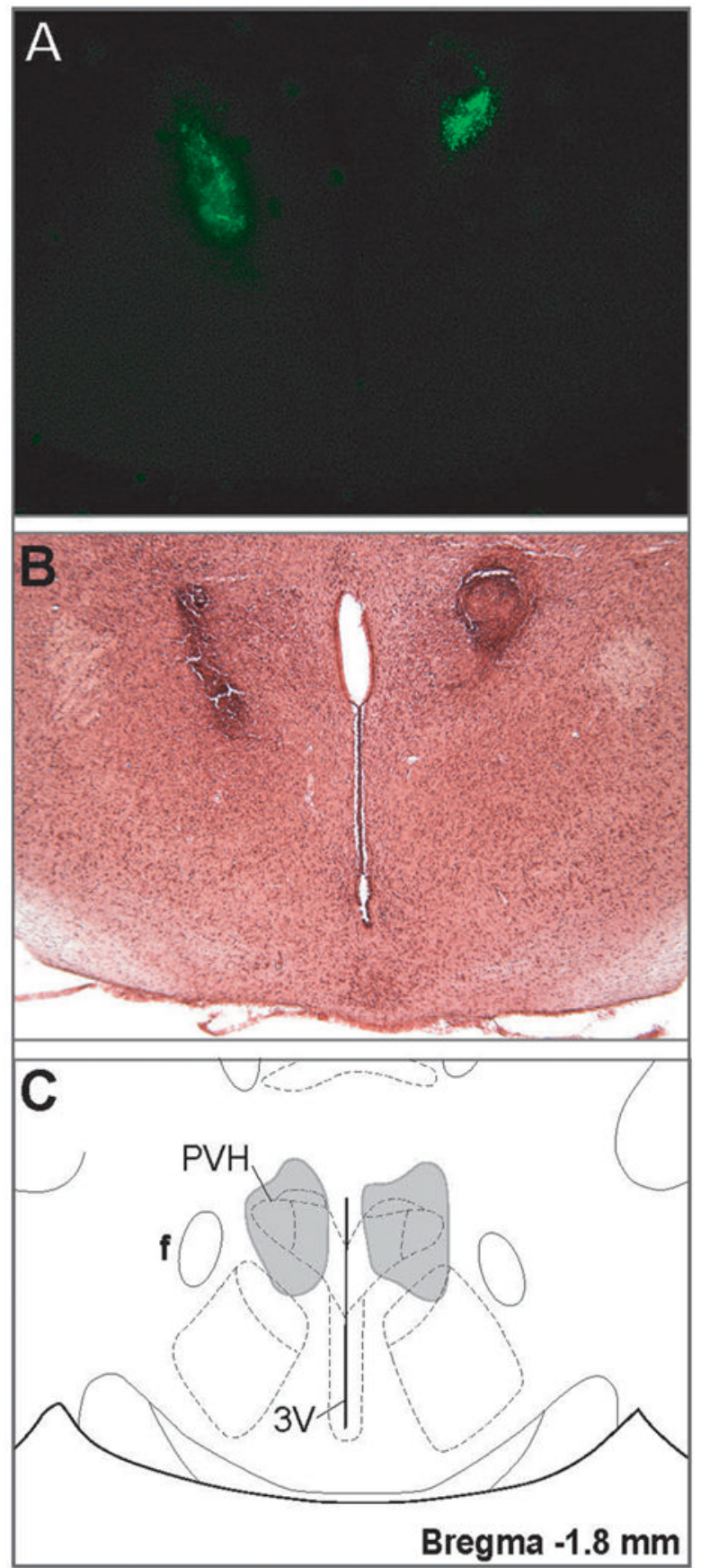

Fig. 2.

Injection sites. Figure A and B show the injection site of a single, representative, animal. The distribution of green fluorescent microspheres (A) marks the sites of a muscimol injection into the region of PVH. The neutral red counterstained section (B) shows the anatomic landmarks used for marking the injection sites. Figure 3C is a schematic, adapted from the atlas of Paxions and Watson [33], summarizing the microinjection sites for studies employing muscimol, WAY, and aCSF. The gray schematic in each figure represents the cumulative spread of fluorescent microspheres co-microinjected with drug or aCSF. Each region shown is a representative; injections may have extended anteriorly or posteriorly by 
no more than $0.5 \mathrm{~mm}$. Abbreviations: $\mathrm{PVH}=$ paraventricular hypothalamus, $\mathrm{f}=$ fornix, $3 \mathrm{~V}=3^{\text {rd }}$ ventricle. 


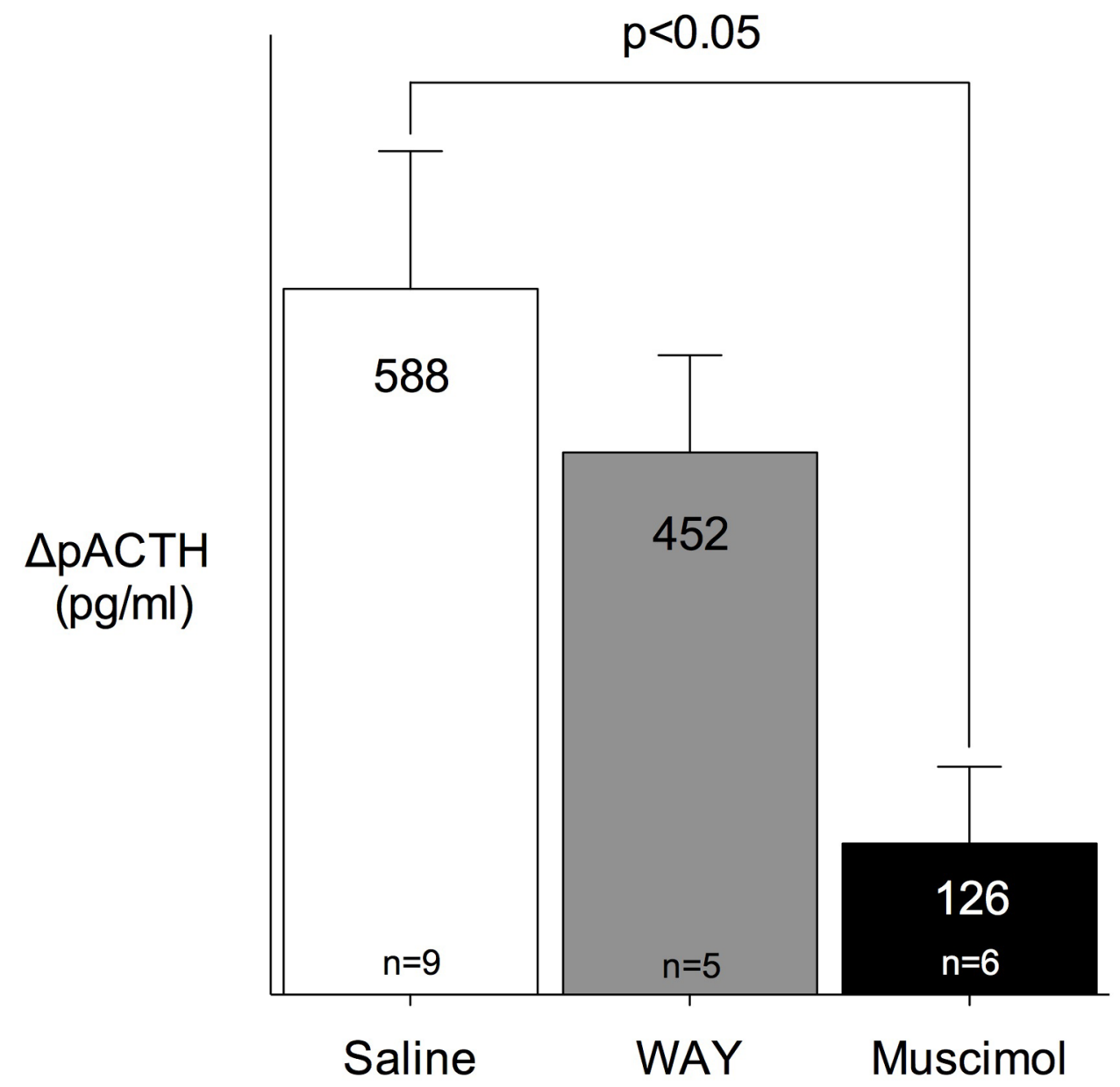

Fig. 3.

The effect of microinjections of muscimol, WAY, or aCSF into the PVH on MDMAmediated increases in ACTH: Vertical rectangular bars and their corresponding numbers represent the mean change in plasma ACTH after a dose of MDMA $(7.5 \mathrm{mg} / \mathrm{kg})$ in animals previously microinjected into the PVH, with either aCSF, muscimol (80 pmol/100nl) or WAY $(0.5 \mathrm{nmol} / 100 \mathrm{nl})$. Error bars represent $1 \mathrm{SEM}$. The number of animals in each group is noted by the number at the base of each vertical rectangular bar. $P$-values were calculated using ANOVA with a Tukey's HSD post hoc analysis. 